\title{
PENGARUH BATU API DARI DAERAH MASOHI-MALUKU TENGAH TERHADAP KUAT TEKAN BETON
}

\author{
Ginardy Husada, Youlanda Luanmase \\ Jurusan Teknik Sipil, Universitas Kristen Maranatha \\ Jalan Prof. Drg. Suria Sumantri MPH. 65, Bandung, 40164 \\ E-mail: betaagin@yahoo.com
}

\begin{abstract}
ABSTRAK
Studi ekperimental uji kuat tekan beton, dimana agregat kasar yang pada umumnya dipakai untuk campuran beton, akan diganti dengan batu api yang berasal dari daerah Masohi-Maluku Tengah, yang mana mempunyai potensi untuk menaikkan mutu beton. Benda uji yang dipakai dalam penelitian ini berbentuk silinder berdiameter $150 \mathrm{~mm}$ dan tinggi $300 \mathrm{~mm}$ dengan mutu beton $25 \mathrm{MPa}$. Perencanaan campuran beton berdasarkan metode SK-SNI-T-15-1990-03. Persentase batu api yang digunakan adalah 10\%, 30\%, 50\%, dan 100\%. Benda uji yang dibuat berjumlah 45 buah, yaitu masing-masing 9 buah untuk beton normal dan beton yang agregatnya diganti dengan batu api. Pengujian kuat tekan beton dilakukan pada umur 7, 14, dan 28 hari. Hasil percobaan diperoleh bahwa batu api dapat menaikkan mutu beton sampai 11,991 \% terhadap beton normal.
\end{abstract}

Kata kunci: Mutu beton, Batu api.

\begin{abstract}
This article presents an experimental study on testing compressive strength of concrete, where coarse aggregate used in general for concrete mixture will be changed with flint coming from Masohi at the central district Moluccas. This flint has the influence to increase the compressive strength of concrete. The specimen used in this research is concrete cylinder specimen with diameter $150 \mathrm{~mm}$, height 30 $\mathrm{mm}$ and the quality of concrete $25 \mathrm{MPa}$. The forecast of concrete mixture is based on method SKSNI-T-15-1990-03. The flint percentage applied by 10\%, 30\%, 50\% and 100\%. The amounts of the specimens are 45 pieces, which is each 9 pieces of standard concrete and concrete which the aggregate is changed with flint. The testing compressive strength of concrete are performed at ages of 7, 14 and 28 days. The result of experiment is obtained that the flint can boost up the compressive strength of concrete until 11,991\% to normal concrete.
\end{abstract}

Keywords: Strength of concrete, Flint coming.

\section{PENDAHULUAN}

Beton yang digunakan sebagai bahan struktur dalam konstruksi Teknik Sipil, dapat dimanfaatkan dalam banyak hal, terutama untuk memajukan konstruksi pembangunan di Indonesia yang sangat pesat ini. Hal ini tentu saja haruslah didukung oleh adanya material yang tersedia di alam dan dapat dimanfaatkan dengan sebaik-baiknya. Pemanfaatan material yang tersedia di alam dapat memberikan suatu kemudahan dan memberikan keuntungan tersendiri bagi pembangunan khususnya daerah-daerah di Indonesia yang sebagian besar bahan materialnya mudah ditemukan. 
Pada penelitian ini, agregat kasar dalam material campuran beton akan digantikan dengan batu api dari daerah Masohi-Maluku Tengah. Batu api yang tersedia di sekitar pantai ini dimanfaatkan oleh masyarakat sekitar untuk dipergunakan sebagai salah satu material dalam pembuatan konstruksi bangunan. Batu api ini sering dipakai dalam pembangunan rumah-rumah beton, pembuatan jembatan juga sebagai lapisan perkerasan jalan. Gambar 1 memperlihatkan batu api yang banyak dijumpai di sekitar pesisir pantai.
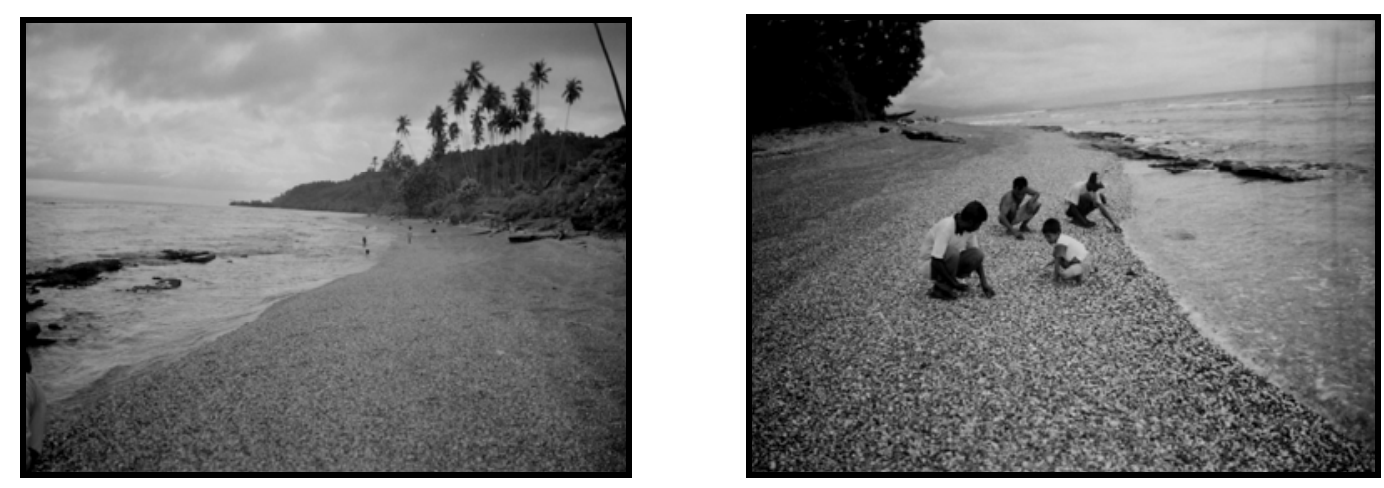

\section{Gambar 1. Batu api di sekitar pesisir pantai Masohi-Maluku Tengah}

Batu api ini sering dipakai dalam pembangunan di daerah Masohi - Maluku Tengah. Selain banyak ditemukan, batu api juga ternyata mempunyai kandungan mineral yaitu mineral kuarsa yang membuat batu ini lebih kuat dibandingkan dengan agregat kasar lain. Untuk itu batu api sangat baik digunakan dalam campuran beton.

Kekerasan mineral dinyatakan dalam skala kekerasan yang dikemukakan oleh seorang ahli mineral Jerman, Friedrich Mohs. Dengan menentukan 10 mineral menurut urutan kekerasannya, disusun suatu standar yang dipakai sebagai pembanding terhadap mineralmineral lain. Menurut skala kekerasannya mineral kuarsa berada pada skala kekerasan 7.

Tujuan penelitian adalah untuk mengetahui mutu dan kekuatan dari batu api sebagai pengganti agregat kasar yang sengaja didatangkan dari daerah Masohi-Maluku Tengah dan membandingkan kuat tekan yang dihasilkan oleh kedua jenis agregat yang berbeda ini dalam campuran beton.

\section{BAHAN-BAHAN DALAM PERENCANAAN CAMPURAN BETON}

\subsection{Semen}

Semen yang digunakan dalam campuran beton adalah semen Portland. Semen Portland diproduksi pertama kali pada tahun 1824 oleh Joseph Aspdin, seorang tukang batu berkebangsaan Inggris. Semen Portland dibentuk dari semen yang dihasilkan menyerupai 
batuan di pulau Portland. Semen Portland didalam ilmu bahan-bahan termasuk dalam golongan bahan perekat hidrolik, yaitu suatu bahan yang akan mengeras bila dicampur dengan air.

Sesuai dengan tujuan penggunaannya, semen Portland dibagi dalam 5 jenis (SK.SNI T-151990-03) yaitu:

a. Tipe I, semen Portland yang dalam penggunaannya tidak memerlukan persyaratan khusus seperti jenis-jenis lainnya

b. Tipe II, semen Portland yang dalam penggunaannya memerlukan ketahanan terhadap sulfat dan panas hidrasi sedang

c. Tipe III, semen Portland yang dalam penggunaannya memerlukan kekuatan awal yang tinggi dalam fase permulaan setelah pengikatan terjadi

d. Tipe IV, semen Portland yang dalam penggunaannya memerlukan panas hidrasi yang rendah

e. Tipe V, semen Portland yang dalam penggunaannya memerlukan ketahanan yang tinggi terhadap sulfat.

\subsection{Agregat}

Kandungan agregat dalam campuran beton biasanya sangat tinggi. Walaupun fungsinya hanya sebagai pengisi, karena komposisinya yang cukup besar, agregat inipun menjadi penting, karena itu perlu dipelajari karateristik agregat yang akan menentukan sifat mortar atau beton yang akan dihasilkan.

Secara umum, agregat dapat dibedakan berdasarkan ukurannya, yaitu, agregat kasar dan agregat halus. Batasan antara agregat halus dan agregat kasar berbeda antara disiplin ilmu yang satu dengan yang lainnya. Meski demikian, dapat diberikan batasan ukuran antara agregat halus dan agregat kasar yaitu 4,8 $\mathrm{mm}$ atau 4,75 mm. Agregat kasar adalah batuan yang butirnya lebih besar dari 4,80 $\mathrm{mm}(4,75 \mathrm{~mm})$ dan agregat halus adalah batuan yang lebih kecil dari 4,8 mm (4,75 mm).

\subsubsection{Modulus Halus Butir}

Modulus halus butir (finnes modulus) atau biasa disingkat dengan MHB ialah suatu indek yang dipakai untuk mengukur kehalusan atau kekasaran butir-butir agregat. MHB didefinisikan sebagai jumlah persen kumulatif dari butir agregat yang tertinggal di atas satu set ayakan (38, 19, 9,6, 4,8, 2,4, 1,2, 0,6, 0,3, 0,15 mm), kemudian nilai tersebut dibagi seratus. 
Makin besar nilai MHB suatu agregat berarti semakin besar butiran agregatnya. Umumnya agregat halus mempunyai MHB sekitar 1,5-3,8 dan agregat kasar mempunyai nilai MHB 5,0-8,0. Nilai ini juga dapat dipakai sebagai dasar untuk mencari perbandingan dari campuran agregat. Untuk agregat campuran nilai MHB yang biasa dipakai sekitar 5,06,0. Hubungan ketiga nilai MHB tersebut dapat dinyatakan sebagai berikut:

$$
\begin{aligned}
& \mathrm{W}=(\mathrm{K}-\mathrm{C}) /(\mathrm{C}-\mathrm{P}) \times 100 \% \\
& \text { dimana: } \mathrm{W}=\text { Berat agregat halus terhadap berat agregat kasar } \\
& \mathrm{K}=\text { Modulus halus butir agregat kasar } \\
& \mathrm{P}=\text { Modulus halus butir agregat halus } \\
& \mathrm{C}=\text { Modulus halus butir agregat campuran. }
\end{aligned}
$$

\subsubsection{Serapan Air}

Serapan air dihitung dari banyaknya air yang mampu diserap oleh agregat pada kondisi jenuh permukaan kering (JPK) atau saturated surface dry (SSD), kondisi ini merupakan:

1. Keadaan kebasahan agregat yang hampir sama dengan agregat dalam beton, sehingga agregat tidak menambah maupun mengurangi air dari pastanya

2. Kadar air di lapangan lebih banyak mendekati kondisi SSD daripada kondisi kering tungku.

\subsubsection{Kadar Air}

Kadar air adalah banyaknya air yang terkandung dalam suatu agregat. Kadar air agregat dapat dibedakan menjadi empat jenis:

1. Kadar air kering tungku yaitu keadaan yang benar-benar tidak berair

2. Kadar air kering udara yaitu kondisi agregat yang permukaannya kering tetapi sedikit mengandung air dalam porinya dan masih dapat menyerap air

3. Jenuh Kering Permukaan (JPK), yaitu keadaan dimana tidak ada air di permukaan agregat, tetapi agregat tersebut masih mampu menyerap air. Pada kondisi ini, air dalam agregat tidak akan menambah atau mengurangi air pada campuran beton

4. Kondisi basah, yaitu kondisi dimana butir-butir agregat banyak mengandung air, sehingga akan menyebabkan penambahan kadar air campuran beton.

Dari keempat kondisi tersebut hanya ada dua kondisi yang sering dipakai yaitu kering tungku dan kondisi SSD. 


\subsubsection{Gradasi Agregat Halus dan Gradasi Agregat Campuran}

Dalam pengerjaan beton yang banyak dipakai adalah agregat normal dengan gradasi yang harus memenuhi syarat. Gradasi yang baik kadang sangat sulit didapatkan langsung dari suatu tempat (quarry). Dalam praktek, biasanya dilakukan pencampuran agar didapatkan gradasi yang baik antara agregat kasar dengan agregat halus.

\subsection{Air}

Air yang dapat diminum umumnya dapat digunakan sebagai campuran beton. Air yang mengandung senyawa-senyawa yang berbahaya, yang tercemar misalnya garam, minyak, gula, atau bahan kimia lainnya, bila dipakai dalam campuran beton akan menurunkan kualitas beton, bahkan dapat mengubah sifat-sifat beton yang dihasilkan.

\subsection{Beton}

Secara umum beton sangat tergantung pada komposisi campuran (perbandingan agregat kasar, agregat halus, semen, dan air), mutu bahan-bahan penyusunnya terutama agregat kasar serta agregat halus-nya yaitu kerikil dan pasir. Kuat tekan beton merupakan salah satu kinerja utama beton. Kuat tekan adalah kemampuan beton untuk menerima gaya tekan persatuan luas. Kekuatan tekan beton akan bertambah dengan naiknya umur beton. Kekuatan beton akan naik secara cepat sampai umur 28 hari, tetapi setelah itu kenaikannya relatif kecil.

\subsection{Syarat Perancangan Beton}

\subsubsection{Kuat Tekan Rencana}

Beton yang dirancang harus memenuhi persyaratan kuat tekan rata-rata, yang memenuhi syarat berdasarkan data deviasi standar hasil uji kuat tekan pada umur 28 hari untuk kondisi dan jenis kontruksi yang sama. Persyaratan kuat tekan didasarkan pada hasil uji kuat tekan silinder.

\subsubsection{Berat Jenis Agregat Normal menurut SII.0052 - 80}

Agregat normal (campuran agregat kasar dan agregat halus) dihasilkan dari pemecahan batuan dengan quarry atau langsung dari sumber alam. Berat jenis rata-ratanya adalah 2,5-2,7. 


\subsubsection{Agregat Normal menurut SII.0052-80}

Agregat halus

1. Modulus halus butir 1,5 sampai 3,8

2. Kadar lumpur atau bagian yang lebih kecil dari 70 mikron $(0,074 \mathrm{~mm})$ maksimum $5 \%$

3. Kadar zat organik yang terkandung ditentukan dengan mencampur agregat halus dengan larutan natrium sulfat $\left(\mathrm{NaSO}_{4}\right) 3 \%$, jika dibanding dengan warna standar/pembanding tidak lebih tua dari warna standar

4. Kekekalan (jika diuji dengan natrium sulfat bagian yang hancur maksimum 10\%, dan jika dipakai magnesium sulfat, maksimum 15\%).

\section{Agregat Kasar}

1. Modulus halus butir 5,0 sampai 8,0

2. Kadar lumpur atau bagian yang lebih kecil dari 70 mikron $(0,074 \mathrm{~mm})$ maksimum $1 \%$

3. Kadar bagian yang lemah jika diuji dengan goresan batang tembaga maksikum 5\%

4. Kekekalan jika diuji dengan natrium sulfat bagian yang hancur maksimum 12\%, dan jika dipakai magnesium sulfat bagian yang hancur maksimum 18\%

5. Tidak bersifat reaktif terhadap alkali jika kadar alkali dalam semen sebagai $\mathrm{Na}_{2} \mathrm{O}$ lebih besar dari $0,6 \%$

6. Tidak mengandung butiran yang panjang dan pipih lebih dari $20 \%$

7. Kekerasan agregat harus memenuhi syarat Tabel 1.

Tabel 1. Syarat mutu kekuatan agregat

\begin{tabular}{|c|c|c|c|}
\hline \multirow[t]{2}{*}{$\begin{array}{l}\text { Kelas dan Mutu } \\
\text { Beton }\end{array}$} & \multicolumn{2}{|c|}{$\begin{array}{l}\text { Kekerasan dengan bejana } \\
\text { Rudelloff, bagian yang } \\
\text { hancur menembus ayakan } 2 \\
\text { mm, persen (\%) maksimum }\end{array}$} & \multirow{2}{*}{$\begin{array}{c}\text { Kekerasan dengan } \\
\text { bejana Los Angelos, } \\
\text { Bagian hancur } \\
\text { menembus aykan 1,7 } \\
\text { mm, \% maks. }\end{array}$} \\
\hline & $\begin{array}{l}\text { Fraksi Butir } \\
9,5-19 \mathrm{~mm}\end{array}$ & $\begin{array}{c}\text { Fraksi Butir } \\
19-30 \mathrm{~mm}\end{array}$ & \\
\hline (1) & $(2)$ & (3) & (4) \\
\hline $\begin{array}{l}\text { Beton Kelas I dan mutu } \mathrm{B}_{0} \\
\text { dan } \mathrm{B}_{1}\end{array}$ & $22-30$ & $24-32$ & $40-50$ \\
\hline $\begin{array}{l}\text { Beton Kelas II dan mutu K. } \\
\text { 125, K175 dan K.225 }\end{array}$ & $14-22$ & $16-24$ & $27-40$ \\
\hline $\begin{array}{l}\text { Beton Kelas III dan mutu > } \\
\text { K. } 225 \text { atau beton pratekan. }\end{array}$ & $\begin{array}{l}\text { Kurang dari } \\
\quad 14\end{array}$ & $\begin{array}{l}\text { Kurang dari } \\
\quad 16\end{array}$ & $\begin{array}{l}\text { Kurang dari } \\
\quad 27\end{array}$ \\
\hline
\end{tabular}

Sumber : SII-0052-80 


\subsection{Perencanaan Proporsi Campuran}

\subsubsection{Kuat Tekan Rata-rata yang Direncanakan}

Nilai standar deviasi didapat dari hasil pengujian yang lalu untuk kondisi pekerjaan dan lingkungan yang sama dengan benda uji yang lebih besar dari 30 benda uji yang berpasangan. Standar deviasi dapat dinyatakan sebagai berikut:

$$
s=\sqrt{\frac{\sum_{i=1}^{n}\left(x_{i}-\bar{x}\right)^{2}}{n-1}}
$$

dimana $s$ adalah standar deviasi, $\mathrm{x}_{\mathrm{i}}$ adalah kuat tekan beton yang didapat dari hasil pengujian untuk masing-masing benda uji, $\bar{x}$ adalah kuat tekan rata-rata dan $n$ adalah jumlah data. Perhitungan nilai standar deviasi awal ditentukan dari data yang diambil dari Tabel 2.2 .

Tabel 2. Faktor pengali untuk deviasi standar untuk perencanaan awal

\begin{tabular}{|c|c|}
\hline $\begin{array}{c}\text { Tingkat Pengendalian Mutu } \\
\text { Pekerjaan }\end{array}$ & S (MPa) \\
\hline Memuaskan & 2,8 \\
Sangat Baik & 3,5 \\
Baik & 4,2 \\
Cukup & 5,6 \\
Jelek & 7,0 \\
Tanpa Kendali & 8,4 \\
\hline
\end{tabular}

\subsubsection{Nilai Tambah (Margin)}

Nilai tambah atau margin dihitung menurut rumus $\mathrm{m}=\mathrm{k} \mathrm{x} \mathrm{s}$, dimana $\mathrm{m}$ adalah nilai tambah, $\mathrm{k}$ adalah tetapan statistik yang nilainya tergantung pada hasil uji yang lebih rendah dari mutu beton ( $\mathrm{f}_{\mathrm{c}}$ ). $\mathrm{k}$ diambil 1,64 dan s adalah standar deviasi. Sehingga $\mathrm{m}=1,64 \mathrm{~s}$.

Dalam hal ini, kuat tekan rencana yang ditargetkan:

$$
\mathrm{f}^{\prime}{ }_{\mathrm{cr}}=\mathrm{f}_{\mathrm{c}}{ }_{\mathrm{c}}+1,64 \mathrm{~s}
$$

\subsubsection{Pemilihan Faktor Air Semen}

Secara umum diketahui bahwa semakin tinggi nilai FAS, semakin rendah mutu kekuatan beton. Namun demikian, nilai FAS yang semakin rendah tidak selalu berarti bahwa kekuatan beton semakin tinggi. Nilai FAS yang rendah akan menyebabkan kesulitan dalam pengerjaan, yaitu kesulitan dalam pelaksanaan pemadatan yang pada akhirnya akan 
menyebabkan mutu beton menurun. Umumnya nilai FAS minimum yang diberikan sekitar 0,4 dan maksimum 0,65.

\subsubsection{Slump}

Slump ditetapkan sesuai dengan kondisi pelaksanaan pekerjaan agar diperoleh beton yang mudah dituangkan dan dipadatkan. Nilai slump dapat diambil dari Tabel 3.

Tabel 3. Slump yang diisyaratkan untuk berbagai konstruksi

\begin{tabular}{|c|c|c|}
\hline \multirow{2}{*}{ Jenis Konstruksi } & \multicolumn{2}{|c|}{$\begin{array}{c}\text { Slump } \\
(\mathrm{mm})\end{array}$} \\
\cline { 2 - 3 } & Maksimum* & Minimum \\
\hline Dinding Penahan dan Pondasi & 76.2 & 25.4 \\
Pondasi sederhana, sumuran, dan dinding sub struktur & 76.2 & 25.4 \\
Balok dan dinding beton & 101.6 & 25.4 \\
Kolom struktural & 101.6 & 25.4 \\
Perkerasan dan slab & 76.2 & 25.4 \\
Baton masal & 50.8 & 25.4 \\
\hline
\end{tabular}

\subsubsection{Kadar Air Bebas}

Kadar air bebas ditentukan oleh agregat yang dipecah atau agregat yang tak pecah (alami) menggunakan Tabel 4 dan agregat campuran dihitung menurut rumus:

Kadar air bebas $=2 / 3 \mathrm{~W}_{\mathrm{h}}+1 / 3 \mathrm{~W}_{\mathrm{k}}$

dimana $\mathrm{W}_{\mathrm{h}}$ adalah perkiraan jumlah air untuk agregat halus dan $\mathrm{W}_{\mathrm{k}}$ adalah perkiraan jumlah air untuk agregat kasar.

Tabel 4. Perkiraan kadar air bebas $\left(\mathrm{kg} / \mathrm{m}^{3}\right)$ yang dibutuhkan untuk

beberapa tingkat kemudahan pekerjaan adukan

\begin{tabular}{|c|l|c|c|c|c|}
\hline \multirow{2}{*}{$\begin{array}{c}\text { Ukuran Besar } \\
\text { Butir Agregat } \\
\text { Maksimum } \\
(\mathrm{mm})\end{array}$} & Jenis Agregat & \multicolumn{4}{|c|}{$\begin{array}{c}\text { Slump } \\
(\mathrm{mm})\end{array}$} \\
\cline { 3 - 6 } & & $0-10$ & $10-30$ & $30-60$ & $60-100$ \\
\hline \multirow{2}{*}{10} & Batu tak pecah & 150 & 180 & 205 & 225 \\
& Batu pecah & 180 & 205 & 230 & 250 \\
\hline \multirow{2}{*}{20} & Batu tak pecah & 135 & 160 & 180 & 195 \\
& Batu pecah & 170 & 190 & 210 & 225 \\
\hline \multirow{2}{*}{30} & Batu tak pecah & 115 & 140 & 160 & 175 \\
& Batu pecah & 155 & 175 & 190 & 205 \\
\hline
\end{tabular}

\subsubsection{Proporsi Agregat Halus}

Proporsi agregat halus ditentukan berdasarkan nilai ukuran butir maksimum yang dipakai, faktor air semen, dan nilai slump yang digunakan serta zona gradasi agregat halus. 


\subsubsection{Berat Jenis Relatif Agregat}

Berat jenis relatif agregat diambil berdasarkan data hasil pengujian laboratorium. Jika data tersebut tidak ada, untuk agregat kasar diambil nilai 2,6 gr/ $\mathrm{cm}^{3}$ dan untuk agregat halus diambil nilai 2,7 $\mathrm{gr} / \mathrm{cm}^{3}$. Berat jenis agregat gabungan dihitung berdasarkan persamaan sebagai berikut:

Berat Jenis (BJ) Agregat Gabungan = [\% Agregat Halus x BJ Agregat Halus $]+$

$$
\text { [\% Agregat Kasar x BJ Agregat Kasar] }
$$

Nilai agregat gabungan kemudian diplotkan kedalam Gambar 2.1, untuk mendapatkan berat jenis beton dalam keadaan basah.

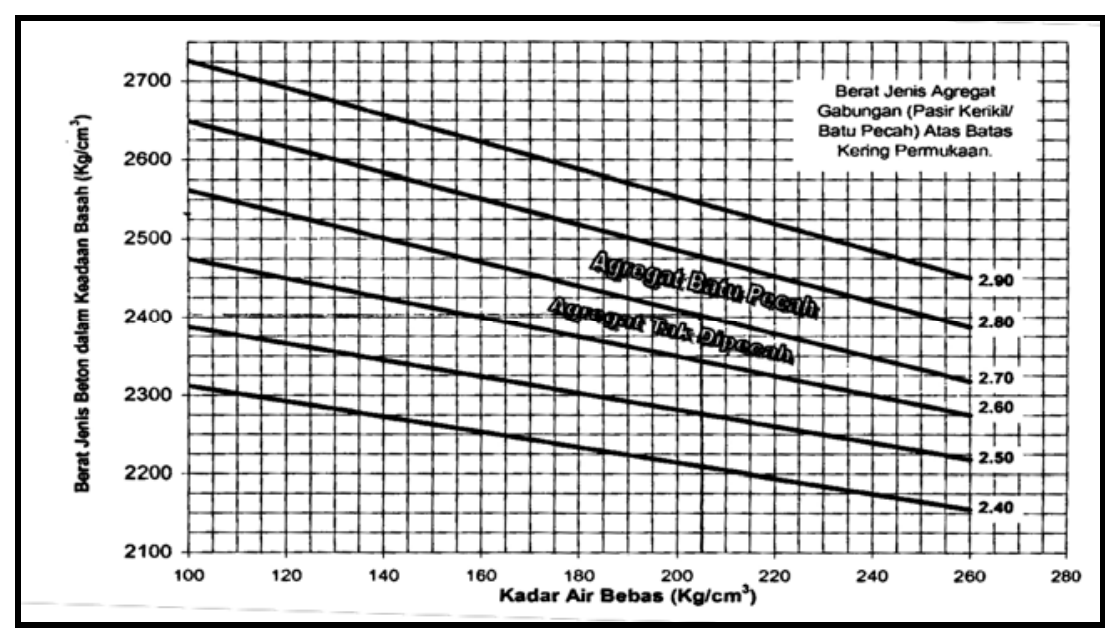

Gambar 2.1 Perkiraan berat jenis beton basah yang dimampatkan secara penuh

\subsubsection{Koreksi Proporsi Campuran}

Apabila agregat tidak dalam keadaan jenuh kering permukaan (SSD), proporsi campuran harus dikoreksi terhadap kandungan dalam agregat. Koreksi proporsi campuran dilakukan terhadap kadar air dalam agregat minimum satu kali dalam sehari dan dihitung menurut rumus sebagai berikut:

Air $\quad=B-\left(C_{k}-C_{a}\right) \times C / 100-\left(D_{k}-D_{a}\right) \times D / 100$

Agregat halus $=\mathrm{C}+\left(\mathrm{C}_{\mathrm{k}}-\mathrm{C}_{\mathrm{a}}\right) \times \mathrm{C} / 100$

Agregat kasar $=\mathrm{D}+\left(\mathrm{D}_{\mathrm{k}}-\mathrm{D}_{\mathrm{a}}\right) \times \mathrm{C} / 100$

$$
\begin{aligned}
\text { dimana: } & \mathrm{B}=\text { Jumlah air }\left(\mathrm{kg} / \mathrm{m}^{3}\right) \\
\mathrm{C} & =\operatorname{Jumlah} \text { agregat halus }\left(\mathrm{kg} / \mathrm{m}^{3}\right) \\
\mathrm{D} & =\text { Jumlah kerikil }\left(\mathrm{kg} / \mathrm{m}^{3}\right)
\end{aligned}
$$




$$
\begin{aligned}
& C_{a}=\text { Penyerapan air agregat halus (\%) } \\
& D_{a}=\text { Penyerapan air agregat kasar (\%) } \\
& C_{k}=\text { Kandungan air agregat halus (\%) } \\
& D_{k}=\text { Kandungan air agregat kasar (\%). }
\end{aligned}
$$

\section{PELAKSANAAN CAMPURAN}

\subsection{Pemeriksaan Material}

Sebelum melaksanakan pencampuran beton ada baiknya dilakukan pemeriksaan material. Pemeriksaan ini dilakukan di Laboratorium Teknologi Beton, Jurusan Teknik Sipil, Universitas Kristen Maranatha, Bandung. Pemeriksaan yang dilakukan antara lain:

1. Penentuan kadar lumpur agregat halus

2. Kadar air agregat kasar, halus dan batu api

3. Berat jenis dan penyerapan agregat halus, kasar dan batu api

4. Kekerasan agregat kasar dan batu api

5. Analisa ayak agregat kasar, halus dan batu api

6. Menentukan slump beton

7. Pemeriksaan kuat tekan beton.

\subsection{Perencanaan Proporsi Gabungan Agregat}

Tujuan dari perhitungan perencanaan proporsi agregat gabungan ini adalah untuk mendapatkan suatu variasi campuran agregat kasar dan halus. Agar menghasilkan campuran beton dengan kemampatan yang baik. Hasil dan perhitungan analisa ayak agregat kasar, batu api, dan agregat halus akan dipakai dalam perhitungan perencanaan proporsi agregat gabungan ini dengan persen batu api 10\%, 30\%, 50\%, dan 100\%.

\subsection{Perencanaan Proporsi Pencampuran Beton}

Untuk mendapatkan proporsi campuran beton maka, harus dilakukan perhitungan terhadap jumlah semen, agregat, dan air dalam 1 sampel silinder. Dan hasil yang diperoleh dapat dilihat pada Tabel 5 merupakan kebutuhan sampel campuran beton.

Tabel 5. Kebutuhan sampel proporsi campuran beton

\begin{tabular}{|c|c|c|c|c|}
\hline $\begin{array}{c}\text { Banyaknya benda uji } \\
\text { untuk }(7,14,28) \text { hari }\end{array}$ & Semen & Air & Agregat Halus & Agregat Kasar \\
\cline { 2 - 5 } & $(\mathrm{kg})$ & $(\mathrm{kg})$ & $(\mathrm{kg})$ & $(\mathrm{kg})$ \\
\hline Proporsi $\left(\mathrm{Kg} / \mathrm{m}^{3}\right)$ & 366 & 246,04 & 822,86 & 980,1 \\
\hline 1 Sampel Silinder $(\mathrm{Kg})$ & 1,9403 & 1,304 & 4,362 & 5,196 \\
\hline
\end{tabular}


Setiap 1 sampel silinder pada Tabel 3.1 proporsi untuk semen, air, agregat halus, agregat kasar dikalikan dengan volume silinder. Untuk 1 sampel silinder kadar semen, air dan agregat halus tidak berubah atau tetap. Yang mengalami perubahan adalah agregat kasar terhadap batu api. Hal ini dapat dilihat pada perhitungan dibawah ini.

Jumlah 1 sampel silinder untuk agregat kasar $=5,196 \mathrm{~kg}$

Maka, untuk masing-masing persen batu api adalah:

1. Batu api $10 \%$

$$
\begin{array}{ll}
=5,196 * 10 \% & =0,5196 \mathrm{~kg} \\
=5,196-0,5196 & =4,6764 \mathrm{~kg} \\
=5,196 * 30 \% & =1,5588 \mathrm{~kg} \\
=5,196-1,5588 & =3,6372 \mathrm{~kg} \\
=5,196 * 50 \% & =2,598 \mathrm{~kg} \\
=5,196-2,598 & =2,598 \mathrm{~kg} \\
=5,196 * 100 \% & =5,196 \mathrm{~kg}
\end{array}
$$$$
\text { Agregat kasar }
$$

Agregat kasar

Agregat kasar

4. Batu api $100 \%$

\section{PEMBAHASAN DAN ANALISIS HASIL PENELITIAN}

\subsection{Data Hasil Kuat Tekan Beton}

Hasil uji kuat tekan beton di Laboratorium Teknologi Beton, Jurusan Teknik Sipil,

\begin{tabular}{|c|c|c|c|c|c|c|}
\hline No & $\begin{array}{l}\text { Umur } \\
\text { Beton }\end{array}$ & $\begin{array}{l}\text { Beban } \\
\text { Runtuh }\end{array}$ & $\begin{array}{l}\text { Beban } \\
\text { Runtuh }\end{array}$ & $\begin{array}{l}\text { Diameter } \\
\text { Silinder d }\end{array}$ & $\begin{array}{c}\text { Luas } \\
\text { Penampang } \\
\text { Silinder A }\end{array}$ & $\begin{array}{c}\text { Kuat Tekan } \\
\text { Beton }\end{array}$ \\
\hline & (Hari) & $(\mathrm{kN})$ & $(\mathrm{N})$ & $(\mathrm{mm})$ & $\left(\mathrm{mm}^{2}\right)$ & (MPa) \\
\hline 1 & \multirow{3}{*}{7} & 340 & 340000 & 150 & 17678,57 & 19,232 \\
\hline 2 & & 350 & 350000 & 150 & 17678,57 & 19,798 \\
\hline 3 & & 360 & 360000 & 150 & 17678,57 & 20,364 \\
\hline 4 & \multirow{3}{*}{14} & 432,5 & 432500 & 150 & 17678,57 & 24,465 \\
\hline 5 & & 445 & 445000 & 150 & 17678,57 & 25,172 \\
\hline 6 & & 462,5 & 462500 & 150 & 17678,57 & 26,162 \\
\hline 7 & \multirow{3}{*}{28} & 490 & 490000 & 150 & 17678,57 & 27,717 \\
\hline 8 & & 510 & 510000 & 150 & 17678,57 & 28,848 \\
\hline 9 & & 525 & 525000 & 150 & 17678,57 & 29,697 \\
\hline
\end{tabular}
Universitas Kristen Maranatha diperoleh data hasil uji kuat tekan beton untuk setiap campuran. Dalam hal ini campuran beton dengan agregat kasar, juga beton dengan batu api sebagai pengganti agregat kasar dengan persentase 10\%, 30\%, 50\%, dan 100\% dalam berbagai umur beton, yaitu umur 7, 14, dan 28 hari. Data-data tersebut tercantum dalam Tabel 6 sampai Tabel 10.

Tabel 6. Data hasil uji kuat tekan beton dengan agregat kasar 
Tabel 7. Data hasil uji kuat tekan beton dengan batu api $10 \%$

\begin{tabular}{|c|c|c|c|c|c|c|}
\hline No & $\begin{array}{l}\text { Umur } \\
\text { Beton }\end{array}$ & $\begin{array}{l}\text { Beban } \\
\text { Runtuh }\end{array}$ & $\begin{array}{l}\text { Beban } \\
\text { Runtuh }\end{array}$ & $\begin{array}{l}\text { Diameter } \\
\text { Silinder d }\end{array}$ & $\begin{array}{c}\text { Luas } \\
\text { Penampang } \\
\text { Silinder A } \\
\end{array}$ & $\begin{array}{c}\text { Kuat Tekan } \\
\text { Beton }\end{array}$ \\
\hline & (Hari) & $(\mathrm{kN})$ & (N) & $(\mathrm{mm})$ & $\left(\mathrm{mm}^{2}\right)$ & (MPa) \\
\hline 1 & \multirow{3}{*}{7} & 342,5 & 342500 & 150 & 17678,57 & 19,374 \\
\hline 2 & & 355 & 355000 & 150 & 17678,57 & 20,081 \\
\hline 3 & & 362,5 & 362500 & 150 & 17678,57 & 20,505 \\
\hline 4 & \multirow{3}{*}{14} & 435 & 435000 & 150 & 17678,57 & 24,606 \\
\hline 5 & & 460 & 460000 & 150 & 17678,57 & 26,020 \\
\hline 6 & & 462,5 & 462500 & 150 & 17678,57 & 26,162 \\
\hline 7 & \multirow{3}{*}{28} & 495 & 495000 & 150 & 17678,57 & 28,000 \\
\hline 8 & & 512,5 & 512500 & 150 & 17678,57 & 28,990 \\
\hline 9 & & 525 & 525000 & 150 & 17678,57 & 29,697 \\
\hline
\end{tabular}

Tabel 8. Data hasil uji kuat tekan beton dengan batu api $\mathbf{3 0 \%}$

\begin{tabular}{|c|c|c|c|c|c|c|}
\hline No & $\begin{array}{l}\text { Umur } \\
\text { Beton }\end{array}$ & $\begin{array}{l}\text { Beban } \\
\text { Runtuh }\end{array}$ & $\begin{array}{l}\text { Beban } \\
\text { Runtuh }\end{array}$ & $\begin{array}{l}\text { Diameter } \\
\text { Silinder d }\end{array}$ & $\begin{array}{c}\text { Luas } \\
\text { Penampang } \\
\text { Silinder A } \\
\end{array}$ & $\begin{array}{c}\text { Kuat Tekan } \\
\text { Beton }\end{array}$ \\
\hline & (Hari) & $(\mathrm{kN})$ & $(\mathrm{N})$ & $(\mathrm{mm})$ & $\left(\mathrm{mm}^{2}\right)$ & (MPa) \\
\hline 1 & \multirow{3}{*}{7} & 350 & 350000 & 150 & 17678,57 & 19,798 \\
\hline 2 & & 360 & 360000 & 150 & 17678,57 & 20,364 \\
\hline 3 & & 375 & 375000 & 150 & 17678,57 & 21,212 \\
\hline 4 & \multirow{3}{*}{14} & 435 & 435000 & 150 & 17678,57 & 24,606 \\
\hline 5 & & 460 & 460000 & 150 & 17678,57 & 26,020 \\
\hline 6 & & 475 & 475000 & 150 & 17678,57 & 26,869 \\
\hline 7 & \multirow{3}{*}{28} & 515 & 515000 & 150 & 17678,57 & 29,131 \\
\hline 8 & & 525 & 525000 & 150 & 17678,57 & 29,697 \\
\hline 9 & & 525 & 525000 & 150 & 17678,57 & 29,697 \\
\hline
\end{tabular}

Tabel 9. Data hasil uji kuat tekan beton dengan persentase batu api $50 \%$

\begin{tabular}{|c|c|c|c|c|c|c|}
\hline No & $\begin{array}{l}\text { Umur } \\
\text { Beton }\end{array}$ & $\begin{array}{l}\text { Beban } \\
\text { Runtuh }\end{array}$ & $\begin{array}{l}\text { Beban } \\
\text { Runtuh }\end{array}$ & $\begin{array}{l}\text { Diameter } \\
\text { Silinder d }\end{array}$ & $\begin{array}{c}\text { Luas } \\
\text { Penampang } \\
\text { Silinder A } \\
\end{array}$ & $\begin{array}{c}\text { Kuat Tekan } \\
\text { Beton }\end{array}$ \\
\hline & (Hari) & $(\mathrm{kN})$ & $(\mathrm{N})$ & $(\mathrm{mm})$ & $\left(\mathrm{mm}^{2}\right)$ & (MPa) \\
\hline 1 & \multirow{3}{*}{7} & 360 & 360000 & 150 & 17678,57 & 20,364 \\
\hline 2 & & 365 & 365000 & 150 & 17678,57 & 20,646 \\
\hline 3 & & 370 & 370000 & 150 & 17678,57 & 20,929 \\
\hline 4 & \multirow{3}{*}{14} & 450 & 450000 & 150 & 17678,57 & 25,455 \\
\hline 5 & & 455 & 455000 & 150 & 17678,57 & 25,737 \\
\hline 6 & & 475 & 475000 & 150 & 17678,57 & 26,869 \\
\hline 7 & \multirow{3}{*}{28} & 525 & 525000 & 150 & 17678,57 & 29,697 \\
\hline 8 & & 530 & 530000 & 150 & 17678,57 & 29,980 \\
\hline 9 & & 535 & 535000 & 150 & 17678,57 & 30,263 \\
\hline
\end{tabular}


Tabel 10. Data hasil uji kuat tekan beton dengan persentase batu api $100 \%$

\begin{tabular}{|c|c|c|c|c|c|c|}
\hline No & $\begin{array}{l}\text { Umur } \\
\text { Beton }\end{array}$ & $\begin{array}{l}\text { Beban } \\
\text { Runtuh }\end{array}$ & $\begin{array}{l}\text { Beban } \\
\text { Runtuh }\end{array}$ & $\begin{array}{l}\text { Diameter } \\
\text { Silinder d }\end{array}$ & $\begin{array}{c}\text { Luas } \\
\text { Penampang } \\
\text { Silinder A }\end{array}$ & $\begin{array}{c}\text { Kuat Tekan } \\
\text { Beton }\end{array}$ \\
\hline & (Hari) & $(\mathrm{kN})$ & $(\mathrm{N})$ & $(\mathrm{mm})$ & $\left(\mathrm{mm}^{2}\right)$ & (MPa) \\
\hline 1 & \multirow{3}{*}{7} & 372,5 & 372500 & 150 & 17678,57 & 21,070 \\
\hline 2 & & 380 & 380000 & 150 & 17678,57 & 21,494 \\
\hline 3 & & 385 & 385000 & 150 & 17678,57 & 21,778 \\
\hline 4 & \multirow{3}{*}{14} & 465 & 465000 & 150 & 17678,57 & 26,303 \\
\hline 5 & & 475 & 475000 & 150 & 17678,57 & 26,869 \\
\hline 6 & & 480 & 480000 & 150 & 17678,57 & 27,152 \\
\hline 7 & \multirow{3}{*}{28} & 550 & 550000 & 150 & 17678,57 & 31,111 \\
\hline 8 & & 552,5 & 552500 & 150 & 17678,57 & 31,253 \\
\hline 9 & & 565 & 565000 & 150 & 17678,57 & 31,960 \\
\hline
\end{tabular}

\subsection{Analisis Regresi Hasil Uji Kuat Tekan}

Pembahas tentang pengolahan data kuat tekan yang sudah diperoleh lewat hasil pengujian di laboratorium. Dengan memiliki sekumpulan data terganggu yang diperoleh dari hasil penelitian ini maka, dipakai persamaan trendline excel untuk lebih mempermudah menganalisis data terganggu tersebut (S.C. Bloch;2002).

Analisis hasil uji kuat tekan beton untuk campuran beton dengan batu api dapat disimpulkan bahwa pesamaan garis yang dipakai yaitu persamaan polinomial. Persamaan polinomial mempunyai nilai R-kuadrat yang lebih mendekati nilai 1 yaitu 0,993 ini berarti hasil penelitian yang diharapkan tercapai.

Dari data-data kuat tekan dan regresi kuat tekan beton yang diperoleh dari hasil uji dan analisis maka, dilakukan perhitungan tentang faktor konversi yang dilalui pada masa beton mengeras. Faktor konversi dalam kuat tekan perlu diperhatikan karena dapat memperlihatkan perkembangan dan kondisi dari beton itu sendiri.

Dibawah ini adalah hasil mutu beton ( $\left.f^{\prime}{ }_{c}\right)$ yang telah diperoleh dari hasil perhitungan faktor konversi dan standar deviasi. Tabel 11 dibuat untuk dapat melihat bahwa mutu kuat tekan beton yang dicari dari agregat kasar dan masing-masing persen batu api mengalami peningkatan mutu dari perencanaan awal yaitu $25 \mathrm{MPa}$.

Bardasarkan Tabel 11 dapat dihitung berapa persen-kah kenaikan batu api yang diperoleh terhadap agregat kasar. Perhitungan persen kenaikan untuk masing-masing persentase batu api terhadap agregat kasar:

$$
\text { Untuk batu api } 10 \%=\frac{27,924-27,555}{27,555} \times 100 \%=1,339 \%
$$




$$
\begin{aligned}
& \text { Untuk batu api } 30 \%=\frac{28,135-27,555}{27,555} \times 100 \%=2,105 \% \\
& \text { Untuk batu api } 50 \%=\frac{29,194-27,555}{27,555} \times 100 \%=5,948 \% \\
& \text { Untuk batu api } 100 \%=\frac{30,859-27,555}{27,555} \times 100 \%=11,991 \%
\end{aligned}
$$

Berdasarkan perhitungan diatas batu api dapat meningkatkan mutu beton hingga 11,991 \%.

\section{Tabel 11. Hasil mutu beton ( $\left.f_{c}{ }_{c}\right)$ yang dicari dari agregat kasar dan batu api} dengan masing-masing persentasenya

\begin{tabular}{|c|c|c|}
\hline \multirow{2}{*}{ Campuran Beton } & Mutu Beton $\mathrm{f}_{\mathrm{c}}$ \\
\cline { 2 - 3 } & (MPa) \\
\hline \multicolumn{2}{|c|}{ Agregat Kasar } & 27,555 \\
\hline \multirow{3}{*}{ Batu Api } & $10 \%$ & 27,924 \\
\cline { 2 - 3 } & $30 \%$ & 28,135 \\
\cline { 2 - 3 } & $50 \%$ & 29,194 \\
\cline { 2 - 3 } & $100 \%$ & 30,859 \\
\hline
\end{tabular}

\section{KESIMPULAN}

Dari hasil pengujian dilaboratorium, dan evaluasi hasil pengujian dapat diambil kesimpulan bahwa:

1. Agregat halus mempunyai kadar lumpur $<5 \%$ yaitu $3,298 \%$ kondisi ini membuat agregat halus tidak perlu dicuci lagi pada saat pencampuran beton. Berbeda dengan agregat kasar dan batu api yang tidak diukur kadar lumpurnya karena untuk syarat agregat kasar kadar lumpur atau bagian yang lebih kecil dari 70 mikron (0,074 mm) maksimum 1\% tapi ternyata agregat kasar dan batu api pada saringan tersebut memiliki nilai $0 \%$ jadi kedua agregat tersebut tidak memiliki kadar lumpur dan tidak perlu dicuci lagi.

2. Dalam hasil penelitian terlihat bahwa ada perbedaan ketinggian slump pada masingmasing campuran beton. Semakin besar persen pengganti batu api semakin kecil slump yang dihasilkan. Hal ini diakibatkan karena permukaan batu api yang kasar sehingga menyebabkan gesekan antara batu api dan pasta semen tidak mudah lepas sehingga slump yang dihasilkan batu api tidak mudah longsor.

3. Jenis konstruksi yang dapat dipenuhi untuk hasil slump campuran beton pada batu api adalah balok dan dinding beton serta kolom struktural. 
4. Agregat kasar memiliki persen hancur 7,31\% pada tekanan maksimum $120 \mathrm{kN}$ sedangkan batu api memiliki persen hancur 11,563\% pada tekanan maksimum 264 kN. Walaupun persen hancur agregat kasar lebih kecil tetapi batu api memiliki kekuatan agregat 2 kali lebih besar dari agregat kasar karena agregat yang kuat biasanya mempunyai modulus elastisitas (sifat dalam pengujian beban uniaxial) yang lebih tinggi.

5. Batu api memang mempunyai pengaruh yang baik untuk beton dibandingkan dengan agregat kasar pada umur 28 hari. Kenaikan batu api mempengaruhi mutu beton itu sendiri seperti terlihat dibawah ini.

f'c (untuk campuran dengan agregat kasar) $\quad=27,555 \mathrm{MPa}$

f'c (untuk campuran dengan batu api 10\%) = 27,924 MPa

f'c (untuk campuran dengan batu api 30\%) = $=28,135 \mathrm{MPa}$

f'c (untuk campuran dengan batu api 50\%) = 29,194 $\mathrm{MPa}$

f'c (untuk campuran dengan batu api 100\%) = = 30,859 $\mathrm{MPa}$

6. Batu api dapat meningkatkan mutu beton. Dibawah ini adalah persentase kenaikan mutu beton yang dicapai hingga 11,991 \% dalam campuran beton.

$\begin{array}{ll}\text { Batu api } 10 \% & =1,339 \% \\ \text { Batu api 30\% } & =2,105 \% \\ \text { Batu api 50\% } & =5,948 \% \\ \text { Batu api } 100 \% & =11,991 \%\end{array}$

\section{DAFTAR PUSTAKA}

1. Departemen Pekerjaan Umum, (1989), Tata cara rencana pembuatan campuran beton normal, SK.SNI.T-15-1990-03, Cetakan Pertama, Bandung, DPU - Yayasan LPMB.

2. Sagel., R dan H. Kesuma, Gideon, (1994), Pedoman Pekerjaan Beton, Cetakan Ketiga, Penerbit: Erlangga, Jakarta.

3. S. C. Bloch, (2002), Excel untuk Insinyur dan Ilmuwan, Penerbit: Erlangga, Jakarta.

4. Tri Mulyono, (2004), Teknologi Beton, Penerbit: Andi, Yogyakarta. 